\title{
Female sporogenesis in the native Antarctic grass Deschampsia antarctica Desv.
}

\author{
Marcin DOMACIUK ${ }^{1}$, Agata LESZCZUK ${ }^{1}$, Ewa SZCZUKA ${ }^{1}$, \\ Wioleta KELLMANN-SOPYŁA ${ }^{2}$, Justyna KOC $^{2}$ and Irena GIEŁWANOWSKA ${ }^{2,3}$ \\ ${ }^{1}$ Zakład Anatomii i Cytologii Roślin, Wydział Biologii i Biotechnologii, \\ Uniwersytet Marii Curie Skłodowskiej, ul. Akademicka 19, 20-031 Lublin, Poland, \\ ${ }^{2}$ Katedra Fizjologii, Genetyki i Biotechnologii Roślin, Wydział Biologii i Biotechnologii, \\ Uniwersytet Warmińnko-Mazurski w Olsztynie, ul. Oczapowskiego 1A, 10-719 Olsztyn, Poland \\ ${ }^{3}$ Instytut Biochemii i Biofizyki PAN, Zakład Biologii Antarktyki i Polska Stacja Antarktyczna \\ "H. Arctowski", ul. Ustrzycka 10/12, 02-141 Warszawa, Poland \\ *corresponding author: i.gielwanowska@uwm.edu.pl
}

\begin{abstract}
The development of megasporocytes and the functional megaspore formation in Deschampsia antarctica were analyzed with the use of microscopic methods. A single archesporial cell was formed directly under the epidermis in the micropylar region of the ovule without producing a parietal cell. In successive stages of development, the meiocyte was transformed into a megaspore tetrad after meiosis. Most megaspores were arranged in a linear fashion, but some tetrads were T-shaped. Only one of the 60 analyzed ovules contained a cell in the direct proximity of the megasporocyte, which could be an aposporous initial. Most of the evaluated $D$. antarctica ovules featured monosporic embryo sacs of the Polygonum type. Approximately $30 \%$ of ovules contained numerous megaspores that were enlarged. The megaspores were located at chalazal and micropylar poles, and some ovules featured two megaspores - terminal and medial - in the chalazal region, or even three megaspores at the chalazal pole. In those cases, the micropylar megaspore was significantly smaller than the remaining megaspores, and it did not have the characteristic features of functional megaspores. Meiocytes and megaspores of $D$. antarctica contained polysaccharides that were detectable by PAS-reaction and aniline blue staining. Starch granules and cell walls of megasporocytes, megaspores and nucellar cells were PAS-positive. Fluorescent callose deposits were identified in the micropylar end of the megasporocytes. During meiosis and after its completion, thick callose deposits were also visible in the periclinal walls and in a small amount in the anticlinal walls of megaspores forming linear and T-shaped tetrads. Callose deposits fluorescence was not observed in the walls of the nucellar cells.
\end{abstract}

Key words: Antarctic, Deschampsia antarctica, megasporocyte, meiosis, megaspore tetrad, callose. 


\section{Introduction}

West Antarctic, a polar region with an extreme environment, is the habitat of only three flowering plants species (Magnoliophytina) which represent only two families of this most diverse group of vascular plants. Two of them, Colobanthus quitensis (Kunth) Bartl. (Caryophyllaceae) and Deschampsia antarctica Desv. (Poaceae), are native to Antarctica. The third species, Poa апnиa L., was introduced to Antarctica by scientists and tourists visiting the continent (Olech 1996; Hall and Saarinen 2009; Olech and Chwedorzewska 2011). This representative of the grass family continues to be studied extensively due to its anthropogenic origin (Chwedorzewska et al. 2014; Giełwanowska and Kellmann-Sopyła 2015; Kellmann-Sopyła et al. 2015; Kellmann-Sopyła and Giełwanowska 2015). Unlike $P$. annua which was introduced to the Antarctic only decades ago, D. antarctica has been present on that continent for around 10000 years (Lewis-Smith et al. 1994). Deschampsia antarctica has developed various adaptive strategies and mechanisms to survive in Antarctica's hostile climate (Barcikowski et al. 2001; Giełwanowska et al. 2005; Giełwanowska and Szczuka 2005; Parnikoza et al. 2011; Giełwanowska et al. 2015). Its survival was conditioned by specific anatomical and ultrastructural characteristics (Giełwanowska et al. 2015; Giełwanowska and Kellmann-Sopyła 2015), in particular high morphological plasticity of organs and organelles, and the ability to modify physiological processes, including the production and accumulation of large amounts of soluble sugars, mainly sucrose, but also 1-kestose, in vegetative tissues (Pastorczyk et al. 2014) and diaspores (Kellmann-Sopyła et al. 2015). Grasses of the genus Deschampsia colonizing other regions contain significantly lower amounts of soluble carbohydrates (Bystrzejewska 2001; Kellmann-Sopyła et al. 2015).

One of the key factors determining the reproductive success of flowering plants in the Antarctic is the adaptation of reproductive organs and processes taking place in them for formation diasporas capable to germination under different temperature conditions and in long period of time (Kellmann-Sopyła and Giełwanowska 2015).

Deschampsia antarctica is diploid with a 2n $=26$ (Moore 1967; Bennett et al. 1982; Cardone et al. 2009). It uses different life strategies and different systems of reproduction (Corner 1971; Greene and Holtom 1971; Edwards 1974), produces the cleistogamic flowers with self-pollination (autogamy) and chasmogamic flowers to enable cross-pollination (allogamy) (Skottsberg 1954; Moore 1970), although the number of pollen grains produced in comparison with other grasses is very small (Giełwanowska et al.2005). Cleistogamy in this species is closely related to the stress factors, such as a low temperature and high humidity, as is common in Poaceae in the Arctic (Levkovsky et al. 1981).

Previous studies (Giełwanowska et al. 2005; Wódkiewicz et al. 2013) demonstrated that $D$. antarctica plants produce both pollen and seeds during each 
growing season in the Antarctic, but their quantity and quality are determined by weather conditions. Deschampsia antarctica seeds produced in West Antarctic are nearly $100 \%$ viable, and they germinate over a temperature range, from $5^{\circ} \mathrm{C}$ (Frenot and Gloaguen 1994) to $12-30^{\circ} \mathrm{C}$ (Giełwanowska et al. 2005; KellmannSopyła and Giełwanowska 2015).

It is well known that apomictic mode of reproduction is frequent within the Poaceae family (Asker and Jerling 1992). In grasses, apomixis (asexual seed formation) involves mostly apospory, parthenogenesis and pseudogamy (Carneiro et al. 2006).

In the Poaceae apomixis has been most extensively researched in Poa pratensis (Carneiro et al. 2006; Niemann et al. 2012). In this species, an enlarged somatic cell of the nucellus (aposporous initial) gives rise by three mitotic divisions to the unreduced female gametophyte. $P$. pratensis is psedogamous apomict, in which embryos develop before pollination, which is nevertheless necessary for the fertilization of the central cell and the endosperm development as well as the formation of viable seeds (Carneiro et al. 2006; Niemann et al. 2012). According to Niemann et al. (2012), apospory plays a key role in the reproduction of $P$. pratensis, whereas the effectiveness of seed production by diploid parthenogenesis varies across genotypes and is largely hereditary (Mazzucato et al. 1996; Barcaccia et al. 1997; Niemann et al. 2012).

In the ovules of $D$. antarctica plants growing in the maritime Antarctic climate, PAS-positive polysaccharides were observed in meiocyte walls throughout megasporogenesis and in postmeiotic cells. Similar observations were made during megasporogenesis in nearly all analyzed spermatophytes (Rodkiewicz 1970; Bouman 1984; Ünal et al. 2013). Starch globules in megasporocyte cytoplasm and in nucellar cells of $D$. antarctica reacted weakly with periodic acid and Schiff base (PAS). In both young meiocytes and throughout meiosis, small proplastids containing starch granules were scattered evenly in megasporocyte cytoplasm, and unlike in Orchidaceae, they were not clustered at either pole of the elongated meiocyte (Bednara et al. 1977). Large and intensely PAS-positive starch granules in $D$. antarctica ovules are visible under an electron microscope only at the stage of a mature embryo sac (Giełwanowska and Kellmann-Sopyła 2015).

In the aniline blue reaction, fluorescent callose deposits were identified in megasporocyte micropylar region in $D$. antarctica. The callose deposit had the form of a thick, arching disc, and it was observed until the end of megasporogenesis. Several callose deposition patterns in megasporocyte walls were described in various angiosperm species, including Gasteria verrucosa (Rodkiewicz 1970), which develops both homopolar and heteropolar megasporocytes, and where callose is visible in the wall of meiotic cells already at the beginning of prophase and forms a relatively thick, continuous layer during zygotene. Towards the end of meiotic prophase, callose is degraded at the chalazal or micropylar pole where the active megaspore will be located after meiosis. One of the four 
active megaspores is selected based on the specific pattern of callose deposition (Rodkiewicz 1970; Rodkiewicz and Bednara 1976; Wilemse and Van Went 1984).

In previous studies on generative structures and processes in D. antarctica, we were able to describe certain stages in the development of pollen mother cells, ovules and diaspores (Giełwanowska et al. 2005; Giełwanowska and Kellmann-Sopyła 2015; Kellmann-Sopyła and Giełwanowska 2015). However, there is no data on differentiation of megaspore mother cells, megasporogenesis, on the synthesis callose during megasporogenesis in $D$. antarctica and the embryo sac development in this species. In this study attempts were made to describe cytochemical and histochemical changes during the differentiation of the megasporocyte and functional (active) megaspores linked with the development of the female gametophyte in $D$. antarctica, as well as features which could indicate an apomixis in this species.

\section{Materials and methods}

Flower buds of Deschampsia antarctica were collected at different developmental stages from plants grown near the H. Arctowski Polish Antarctic Station and immediately fixed in Carnoy'a fixative (ethanol, acetic acid; 3:1). Fixed flower buds were dehydrated in a graded ethanol series (10\% to 96\%) for $15 \mathrm{~min}$ at each concentration and washed in absolute ethanol three times for 15 min each. The plant material was then impregnated with solutions of absolute ethanol and acetone (3:1, 1:1, 1:3; 30 min each) and embedded in paraffin at $58^{\circ} \mathrm{C}$. For light microscopy, paraffin samples were cut into $7 \mu \mathrm{m}$-thick sections with a rotary microtome and stained with a $1 \%$ aqueous solution of safranin $\mathrm{O}$ and a $0.5 \%$ ethanol solution of light green. The sections were stained with PAS (Schiff's reagent, periodic acid) according to Pearse (1985) to localize insoluble polysaccharides.

The specimens were stained with a $0.05 \%$ aqueous solution of aniline blue and examined under a fluorescence microscope (UV 330-360 nm) to detect callose (Clark 1981). Samples were examined using Nikon Optiphot II optical microscope and images were acquired with a Nikon Coolpix 4500 digital camera.

The isolated ovules of $D$. antarctica were fixed in a mixture of $3.5 \%$ glutaraldehyde and $3.5 \%$ paraformaldehyde in $0.1 \mathrm{M}$ phosphate buffer (PBS) with $\mathrm{pH}$ 7.2. The specimens were rinsed in $0.1 \mathrm{M}$ PBS and additionally fixed in $4 \%$ aqueous solution of osmium tetroxide for $24 \mathrm{~h}$ at room temperature. They were rinsed in distilled water, dehydrated with a graded ethanol series and saturated in 1:3, 1:1 and 3:1 mixtures of LR White resin and acetone for $3 \mathrm{~h}$ each. The prepared specimens were embedded in LR White resin, cut in the Reichert Ultracut S microtome into semi-thin sections of $1.5 \mu \mathrm{m}$ and stained with a $0.5 \%$ 
solution of toluidine blue in $0.5 \%$ borax. Observations were performed under the Optiphot-2 microscope. Images were acquired with the Nikon Coolpix 4500 camera.

\section{Results}

In the natural habitat of West Antarctic, Deschampsia antarctica produces leafy shoots, measuring several centimeters in length, that form dense patches (Fig. 1a). Panicle inflorescences comprise spikelets with several florets (Fig. 1a-c). A single flower features a style composed of two carpels with a plumose, bipartite stigma (Fig. 1e) and three stamens. Four and, rarely, three microsporangia are differentiated in the thecae (Fig. 1c, d). The ovary of D. antarctica contains a single anatropous, tenuinucellate ovule (Fig. 1e, f) with two integuments. An elongated megasporocyte with a large nucleus and nucleolus is differentiated at the micropylar end of the ovule (Fig. 2a). On the chalazal side it is enveloped by dividing nucellar thin-walled cells. During early meiotic prophase, the meiocyte was adjacent to individual subepidermal nucellar cells which divided transversely to form three or four cells and, subsequently, segments of several cells. Three or four rows of nucellar cells arranged in a fanlike pattern were observed in successive stages of development (Fig. 2b-g). The archesporial cell in the ovule of $D$. antarctica was differentiated in the apical part of the nucellus of the anatropous ovule. The archesporial cell did not produce a parietal cell, therefore the megasporocyte and megaspores produced by meiotic division were adjacent to the epidermis at the micropylar end (Fig. 2e, g, j).

Cell organelles in developing $D$. antarctica megasporocytes were not clustered at either pole of an elongated cell. Small organelles, including proplastids with starch granules, were evenly distributed throughout the cytoplasm of meiotic cells.

A cell much larger than the remaining nucellar cells was observed at the base of the megasporocyte, and it was most probably an aposporous initial (Fig. 2a), which suggests that apomixis occurs in D. antarctica.

An active megaspore located closer to the chalazal pole underwent further development, as suggested by the more convex shape of cell walls due to higher turgor pressure of the protoplast and the presence of vacuoles in cytoplasm (Fig. 2d, e). In the course of meiosis, the first heterotypic division produced a dyad of two cells separated by a somewhat thicker wall (Fig. 2b). The chalazal cell in the dyad usually had higher turgor pressure, as demonstrated by the characteristic deformation of cell walls. Moreover, these cells have a similar size and similarly organized protoplasts. In some ovules, the second meiotic phase was not synchronous and meiosis was more advanced in the chalazal cell of dyad. A chalazal cell during metaphase of the second meiotic division is shown in Fig. 2c. At the 

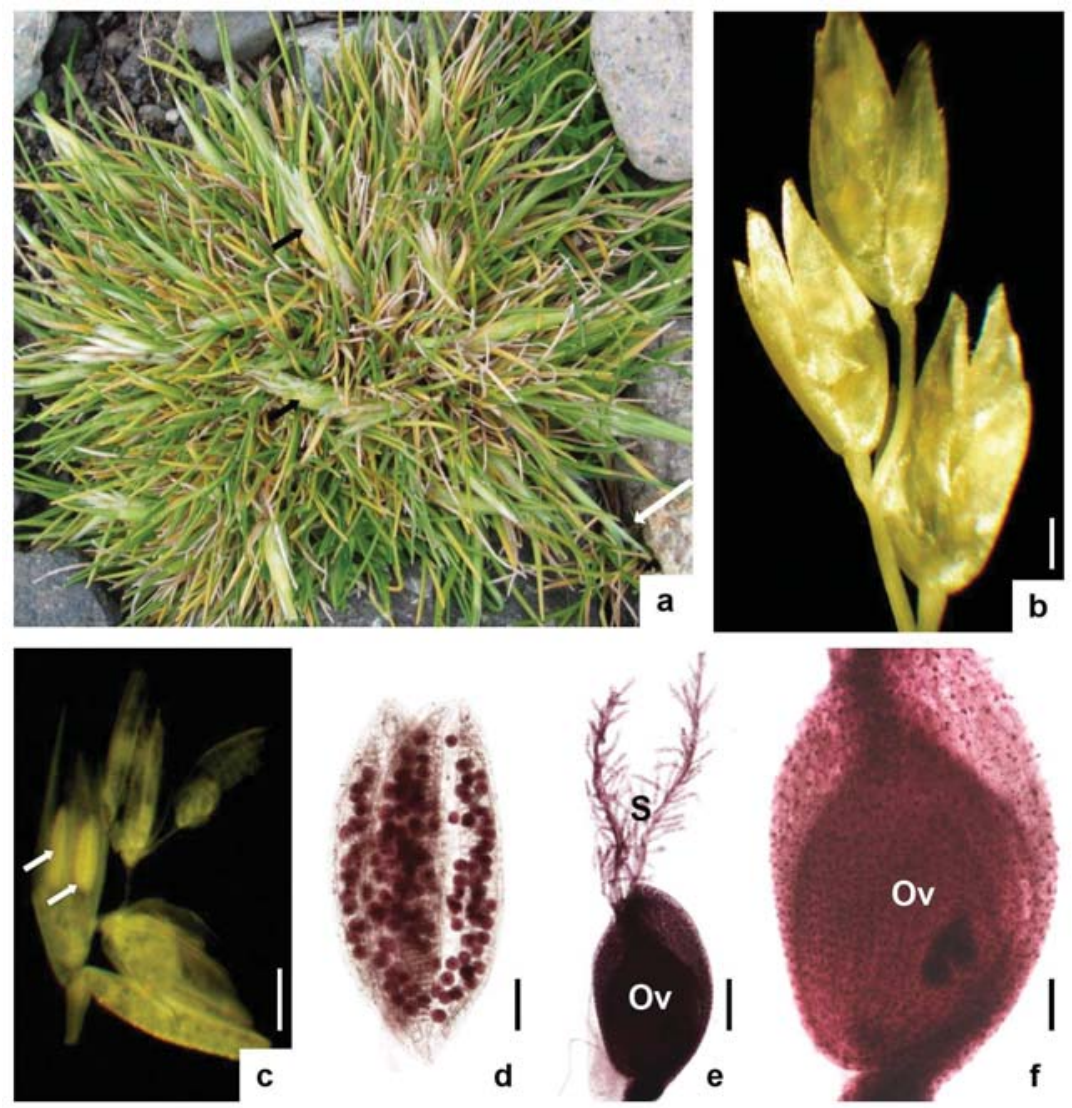

Fig. 1. Morphology of Antarctic hair grass Deschampsia antarctica. a. A small cluster of $D$. antarctica plants growing between stones in the natural habitat. Note the well-developed spikelets (arrows) between small, densely arranged leaves. b. The apical part of the inflorescence contains florets wrapped in glumes and lemmas; scale $1000 \mu \mathrm{m}$. c. Flowers partially dissected from the spikelet with two visible stamens with short filaments and anthers filled with pollen grains are visible (arrows); scale $1000 \mu \mathrm{m}$. d. Anthers filled with pollen grains; scale $100 \mu \mathrm{m}$. e. Carpel with bipartite style and plumose stigma (S); a single-ovule (Ov) is enclosed in the ovary, scale $250 \mu \mathrm{m}$. f. Ovary with a visible single, tenuinucellate ovule (Ov), scale $100 \mu \mathrm{m}$.

same time, the nucleus of a micropylar cell was entering the prophase of meiotic division II. This asynchronous division led to the formation of a megaspore triad (Fig. 2c). Triad and tetrad megaspores were generally similar and differed only in the composition of cell organelles. Plastids were located mostly at micropylar and chalazal poles, and in several tetrads, single starch grains were positioned in medial megaspores. Meiotic division of the megasporocytes led to the formation of megaspore tetrads with various arrangements. Megaspores were arranged in a linear (Fig. 2e) or T-shaped tetrad (Fig. 2f). 

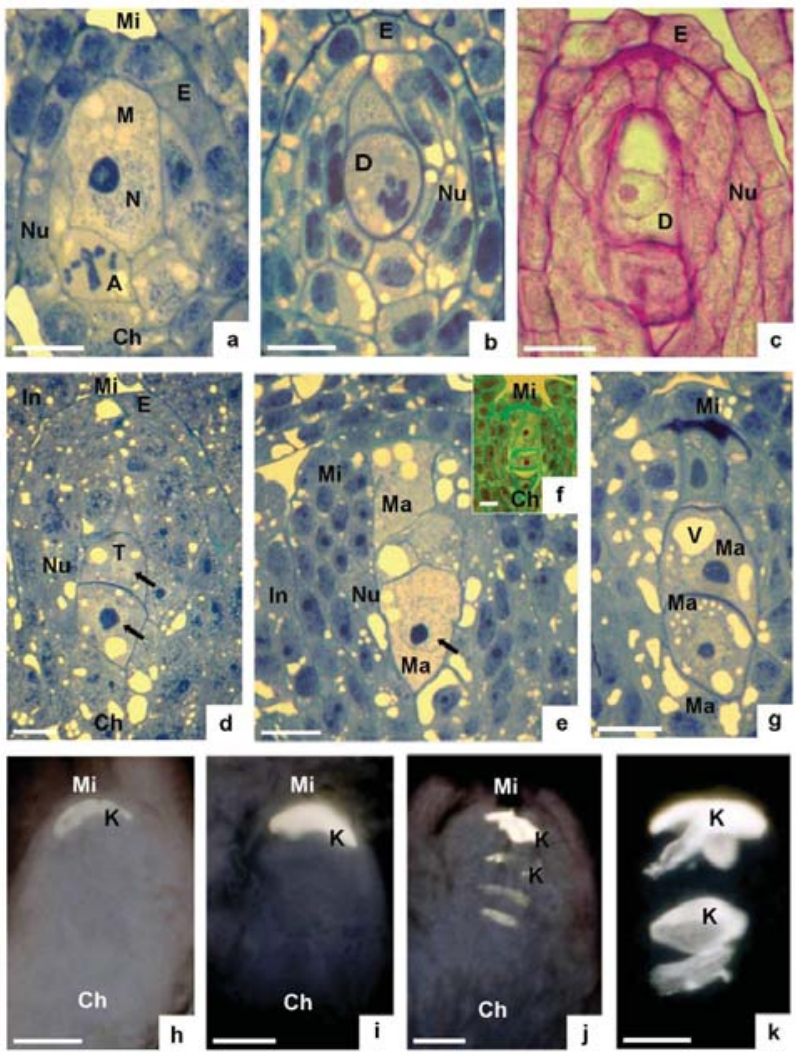

Fig. 2. Megasporogenesis in Deschampsia antarctica. a, b, d, e and g. Longitudinal, semi-thin sections stained with toluidine blue. c. Section stained with PAS-reaction. h-k. Ovule squash preparations with fluorescent callose stained with aniline blue. a. Micropylar part of an ovule showing a megasporocyte (M) located directly under epidermis $(\mathrm{E})$ of the nucellus $(\mathrm{Nu})$. The nucellar cell adjacent to the chalazal part of the megasporocyte divides mitotically (A), scale $25 \mu \mathrm{m}$. Mi and $\mathrm{Ch}$ - micropylar and chalazal parts of the ovule, respectively. $\mathbf{b}$ and $\mathbf{c}$. Dyads formed after the first asymmetric meiotic division. Both dyad cells are surrounded with thick cell walls deeply stained with toluidine blue (b) and PAS (c). Note the larger cell in $\mathbf{b}$ at the chalazal pole in the dyad and in $\mathbf{c}$ in the micropylar pole, scale $25 \mu \mathrm{m}$. d. A triad of megaspores formed after the first and incomplete second meiotic division with two enlarged megaspores - chalazal and medial (arrows), scale $25 \mu \mathrm{m}$. e. A tetrad comprising four linear megaspores of different size. Differently sized vacuoles are visible in the sparse cytoplasm. Note the large nucleus with a large nucleolus in the larger medial megaspore (arrow), scale $25 \mu \mathrm{m}$. f. A T-shaped tetrad of megaspores in an ovule stained with safranin and light green, scale $25 \mu \mathrm{m}$. g. A tetrad of megaspores. Chalazal and medial megaspores are large and similar in size in contrast to the much smaller micropylar megaspore. $\mathrm{V}$ - vacuole, scale $25 \mu \mathrm{m}$. h and $\mathbf{i}$. The outline of ovules with the megasporocyte during prophase of the first meiotic division. h. Fluorescent callose deposit $(\mathrm{K})$ in the micropylar fragment of early prophase megasporocyte cell wall. i. A megasporocyte during a later prophase stage than that shown in $\mathbf{h}$ with a more extended callose deposit at the micropylar pole, scale $25 \mu \mathrm{m}$. j. Fluorescent callose deposits in a megaspore tetrad. Note the larger callose deposit in the micropylar pole and a narrower deposit in the anticlinal walls separating the megaspores, scale $25 \mu \mathrm{m}$. k. A magnified tetrad of megaspores with a somewhat oblique position. Note the large callose deposit in the external wall of the micropylar megaspore and the undulating layers of callose deposits in the anticlinal wall, scale $25 \mu \mathrm{m}$. 
In most ovules a monosporic embryo sac of the Polygonum type developed. Despite the above, in nearly $30 \%$ of ovules, two megaspores located at chalazal and micropylar poles underwent further development (Fig. 2e). In some cases, two megaspores at the chalazal end (terminal and medial) last long and look like a functional megaspores, which was demonstrated by significant vacuolization of protoplast cells in Fig. 2g.

Fluorescent callose deposits in $D$. antarctica ovules were identified in the micropylar end of the megasporocytes wall and their fluorescence increased during meiosis. Callose fluorescence was initially weak (Fig. 2h). Successive sections revealed changes in the shape of callose deposits which became thicker and more disc-shaped (Fig. 2i). After both meiotic divisions, callose deposits were observed on the anticlinal walls of the linear and the T-shaped tetrad (Fig. 2j, k).

In the analyzed $D$. antarctica ovules, the competition between megaspores was not limited to the examples shown in Fig. 2. Both the terminal chalazal megaspore and the medial chalazal megaspore can become functional megaspores (Fig. 3b, c). In the nucellus presented in Figure 3a, both terminal and medial chalazal megaspores are enlarged. The three megaspores on the chalazal side contain similarly sized and more deeply stained protoplasts, which indicates that all three megaspores located at the chalazal pole can act as functional megaspores that undergo further development (Fig. 3e). The micropylar megaspore was rather smaller, without the starch granules, and suggests that it was less active and probably did not undergo further development.

\section{Discussion}

In plants of the family Poaceae, a single-celled archesporium is differentiated from a subepidermal cell in the apical part of the nucellus (Chandra 1963). Unlike in Colobanthus quitensis, the second flowering plant native to the Antarctic, the tenuinucellate ovule of Deschampsia antarctica is characterized by an absence of a parietal cell during the development of archesporial cells (Giełwanowska et al. 2011).

Tetrad megaspores in this species were generally similar and differed only in the composition of cell organelles. Plastids were located mostly at micropylar and chalazal poles. Starch granules accumulating in chalazal and micropylar regions of a megasporocyte were described in orchids, but in successive stages of development, when megasporocytes divided asymmetrically, those grains were found mainly in the active megaspore of the chalazal pole and in degenerating megaspores (Bednara et al. 1977).

Dyad cells and the resulting tetrads of $D$. antarctica megaspores share a PASpositive external wall. The wall envelops a developing meiocyte, and after its division into megaspores, it becomes the external wall of postmeiotic cells. The 

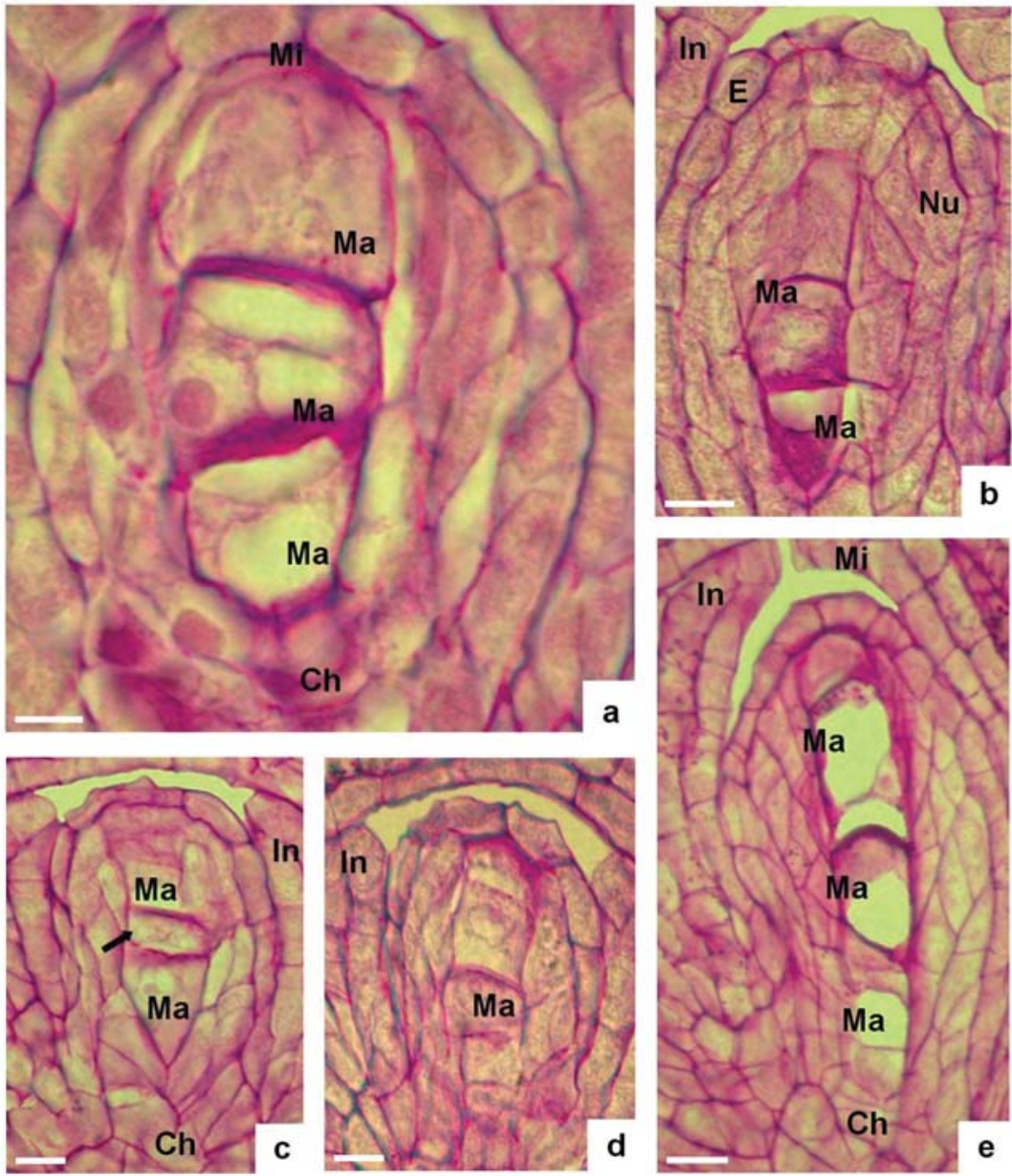

Fig. 3. Different patterns of megaspore differentiation. Longitudinal sections of Deschampsia antarctica ovules stained with PAS-reaction. a-c. A megaspore tetrads. a. Megaspore tetrad with the almost identical megaspores of similar size separated by thick anticlinal walls; only the micropylar megaspore is somewhat larger. b. Two of the three megaspores in the micropylar region and in the center are larger than the chalazal megaspore. c. A tetrad with enlarged micropylar and chalazal megaspores; the medial megaspore (arrow) is much smaller than both terminal megaspores. a. scale $10 \mu \mathrm{m}, \mathbf{b}$ and $\mathbf{c}$. scale $25 \mu \mathrm{m}$. d and e. Tetrads of linear megaspores inside the ovule nucellus. d. A tetrad with a visibly enlarged micropylar megaspore. e. A tetrad of megaspores with three (one chalazal and two medial) enlarged megaspores and a smaller micropylar megaspore. The medial megaspore adjacent to the inactive micropylar megaspore is larger than the remaining megaspores, scale $25 \mu \mathrm{m}$.

wall's structural continuity is preserved, but it undergoes biochemical changes that differentiate it from the walls of somatic cells inside the ovule. Similarly to all investigated angiosperms (Rodkiewicz 1970; Ünal et al. 2013), female meiotic cells in D. antarctica synthesize callose during prophase and deposit 
it on the primary wall, which is not observed in the development of the male meiotic cells in this species (Giełwanowska et al. 2005).

In plant tissues, callose is generally deposited in the primary wall. Callose is produced after every mitotic division, and it is accumulated in small amounts in primary walls during somatic-type cytokinesis of meristem cells in various plants (Waterkeyn 1971; Longly and Waterkeyn 1977). Fluorescence characteristic of callose is detected in plant cells also in response to various stressors, such as pathogenous causing tissue damage (Shimoura and Dijkstra 1975). In sporocytes of flowering plants, callose is frequently observed in microsporocyte and megasporocyte walls where clear differences are noted in callose distribution patterns. In angiosperms, the presence of callose, its accumulation patterns and disappearance during megasporogenesis is clearly linked with cell polarization and the location of active megaspores in a tetrad (Bouman 1984).

The formation of callose walls during meiotic division of megasporocytes was first observed in orchids (Rodkiewicz and Górska-Brylass 1968), and two years later callose walls were identified during megasporogenesis in several dozen species representing 14 angiosperm families (Rodkiewicz 1970).

During megasporogenesis, callose is temporarily present in the cell walls of plants with a monosporic or bisporic embryo sac, but callose walls were not detected during megasporogenesis in plants with a tetrasporic pattern (Rodkiewicz 1970). In plants with a monosporic embryo sac of the Polygonum type, including D. antarctica (Giełwanowska et al. 2005), callose is always formed at the beginning of the first meiotic prophase at the chalazal pole of the megasporocyte, whereas in the first metaphase, the entire meiotic cell is enveloped by a callose wall. In plants with this pattern of development, callose is deposited throughout megasporogenesis until tetrad formation. As a result, every postmeiotic cell is surrounded by callose. In the discussed pattern of development, which is noted in approximately $75 \%$ of angiosperms, callose disappears from the walls of the functional macrospore shortly after megasporogenesis, but it is often retained in the walls of degenerated megaspores (Rodkiewicz 1970).

In $D$. antarctica, the first callose deposit appeared in the micropylar region of the megasporocyte, and it did not spread to the remaining parts of the cell wall. The deposit became thicker, it appears the shape of a convex disc, and it was present until the end of reduction division. Successive callose layers were formed during the development of anticlinal walls after the first and second meiotic division. After megasporogenesis, all megaspores in D. antarctica were separated by thick callose walls and a thick callose deposit on the micropylar side. Fluorescence characteristic of callose was not detected in periclinal walls of megaspores, which suggests that callose was not accumulated in those locations or that it was synthesized in very small quantities or that its deposition was short-lived. Callose deposits that could effectively isolate meiotic cells from nucellar cells were not formed (Bouman 1984; Bell 1996). Thick layers 
of callose in anticlinal walls could separate megaspores over a certain period of time. In addition to the specific organization of protoplasts and distinct cell shapes, this callose distribution pattern in the walls of $D$. antarctica megasporocytes could indicate that megaspores and functional megaspores in the analyzed species could be both homopolar and heteropolar. The callose wall plays an important role in the development of the embryo sac by creating a molecular filter which reduces cell wall permeability. The megasporocyte is thus temporarily separated from the surrounding sporophyte tissues. The isolated cells can undergo individual differentiation, including gene expression between the sporophyte and gametophyte phases (Ünal et al. 2013). In many angiosperms, an active functional macrospore has a callose-free wall which supports free substance flow (Bouman 1984). Inactive megaspores are enveloped by callose walls for a long period of time until they undergo programmed cell death and degeneration (Bell 1996). Numerous authors have observed that temporary callose isolation during sporophyte differentiation plays a key role in cells entering a new, independent developmental pathway (Bouman 1984).

In selected angiosperm taxa, such as Taraxacum, structural differences were not observed between ovarian tissues and ovules in plants involved in generative and apomictic reproduction (Płachno et al. 2015). In several species, close correlations were reported between apomictic processes and cytochemical reactions in the ovules of flowering plants (Koltunow 1993; Ünal et al. 2013). In mentioned taxa it was manifested mostly by the deposition of PAS-positive insoluble polysaccharides. Those polysaccharides are accumulated in plastids.

In many species of flowering plants, cell organelles and starch granules were more likely to cluster in the part of the cell which ultimately gives rise to active tetrad megaspores (Bednara et al. 1977; Bouman 1984). In many species, meiotic division is uneven, and it leads to the formation of a larger functional macrospore and smaller inactive megaspores that are degenerated.

The results obtained in the present study show that the selection of active megaspore in $D$. antarctica is made in accordance with the mechanism typical for the species with megasporogenesis of the Polygonum type. The chalazal megaspore is favored, but often lack of callose in the side walls of meiotic cells sometimes facilitates the development of other megaspore that can compete with chalazal megaspore and compete with each other.

In the analyzed $D$. antarctica ovules callose fluorescence was not observed in nucellar cells in the vicinity of a developing megasporocyte which may mean that they do not develop additional cells which can initiate the development. Each of the sixty-examined ovules contained one megasporocyte and finally, one embryo sac.

Acknowledgments. - The authors thank anonymous reviewers and the Polish Polar Research editorial team for their work. 


\section{References}

ASKeR S. and JeRLING L. 1992. Apomixis in plants. CRC Press, Boca Raton, FL: 298 pp.

Barcikowski A., Czaplewska J., Giełwanowska I., Loro P., SMYKla J. and Zarzycki K. 2001. Deschampsia antarctica (Poaceae) - the only native grass from Antarctica. In: L. Frey (ed.) Studies on grasses in Poland. Szafer Institute of Botany Polish Academy of Sciences, Kraków: 367-377.

Barcaccia G., Mazzucato A., Belardinelli A., Pezzotti M., Lucretti S. and Falcinelli M. 1997. Inheritance of parental genomes in progenies of Poa pratensis L. from sexual and apomictic genotypes as assessed by RAPD markers and flow cytometry. Theoretical and Applied Genetics 95: 516-524.

BEDNARA J., STOBIECKA H. and RodKIEWICZ B. 1977. Ulltrastructure of meiotic cells in ovules of the orchid Epipactis. Acta Medica Polona 18: 285-286.

BELL P.R. 1996. Megaspore abortion: a consequence of selective apoptosis? International Journal of Plant Sciences 157: 1-7.

BenNeTt M.D., SMith J.B. and LEWIS-SMith R.I. 1982. DNA amounts of angiosperms from the Antarctic and South Georgia. Environmental and Experimental Botany 22: 307-318.

Bouman F. 1984. The ovule. In: B.M. Johri (ed.) Embryology of Angiosperms. Springer-Verlag, Berlin, Heidelberg, New York: 123-157.

BySTRZEJEWSKA G. 2001. Photosynthetic temperature response of Antarctic plant Deschampsia antarctica and of temperate region plant Deschampsia cespitosa. Polish Journal of Ecology 49: 215-219.

Cardone S., Sawatani P., Rush P., Garciá A.M., Poggio L. and Schrauf G. 2009. Karyological studies in Deschampsia antarctica Desv. (Poaceae). Polar Biology 32: 427-433.

CARnEIRo V.T.C., Dusi D.M.A. and OrTIZ J.P.A. 2006. Apomixis: Occurrence, applications and improvements. In: J.A. Teixeira da Silva J.A. (ed.) Ornamental and plant biotechnology: Advances and Topical Issues I. Floriculture, Isleworth: 564-571.

ChANDRA N. 1963. Some ovule characters in the systematics of the Gramineae. American Journal of Botany 41: 215-222.

Chwedorzewska K.J., Gieewanowska I., Olech M., Molina-Montenegro M.A., WódKieWICZ M. and GALerA H. 2015. Poa апnиa L. in the maritime Antarctic: an overview. Polar Record 35: 1-7.

ClarK G. 1981. Staining Procedures. 4th ed., Williams and Wilkins: Baltimore, USA: 512 pp.

CORNER R.W.M. 1971. Studies in Colobanthus quitensis (Kunth) Bartl. and Deschampsia antarctica Desv.: V. Distribution and reproductive performance in Argentine Islands. British Antarctic Survey Bulletin 26: 41-50.

EDWARDS J.A. 1974. Studies in Colobanthus quitensis (Kunth) Bartl. and Deschampsia antarctica Desv.: VI. Reproductive performance on Signy Island. British Antarctic Survey Bulletin 39: $67-86$.

FRENOT Y. and GlOAGUEN J.C. 1994. Reproductive performance of native and alien colonizing phanerogams on a glacier foreland, Iles Kerguelen. Polar Biology 14: 473-481.

GIEŁWANOWSKA I., BOCHENEK A. and LORO P. 2005. Biology of generative reproduction of Deschampsia antarctica. In: L. Frey (ed.) Biology of grasses. Szafer Institute of Botany Polish Academy of Sciences, Krakow: 181-195.

GieŁWAnowska I., BocheneK A., GoJŁo E., GóRecki R., Kellmann W., Pastorczyk M. and SzCZUKA E. 2011. Biology of reproduction of Colobanthus quitensis (Kunth) Bartl. Polish Polar Research 32: 139-155. 
GIEŁWANOWSKA I. and KELLMANN-SOPYŁA W. 2015. Generative reproduction of Antarctic grasses, the native species Deschampsia antarctica Desv. and the alien species Poa annua L. Polish Polar Research 36: 261-279

GieŁwanowska I., PastorczyK M., Kellmann-SopyŁa W., GóRniaK D. and GóRecKi R.J. 2015. Morphological and ultrastructural changes of organelles in leaf mesophyll cells of the Arctic and Antarctc plants of Poaceae family under the cold influence. Arctic, Antarctic and Alpine Research 45: 17-25.

GIEŁWANOWSKA I. and SzCZUKA E. 2005. New ultrastructural features of organelles in Deschampsia antarctica Desv. leaf cells. Polar Biology 28: 951-955.

Greene D.M. and Holtom A. 1971. Studies in Colobanthus quitensis (Kunth) Bartl. and Deschampsia antarctica Desv.: III. Distribution, habitats and performance in the Antarctic botanical zone. British Antarctic Survey Bulletin 26: 1-29.

HALl C.M. and SAARINEN J. 2009. Tourism and Change in Polar Regions: Climate, Environments and Experiences. Routledge, Oxon, UK: 317 pp.

Kellmann-SOPYŁA W. and GIEŁWANOWSKA I. 2015. Germination capacity of five polar Caryophyllaceae and Poaceae species under different temperature conditions. Polar Biology 38: $1753-1765$.

Kellmann-SopyŁa W., LAhUta L.B., GieŁwanowsKa I. and GóReCKi R.J. 2015. Soluble carbohydrates in developing and mature diaspores of polar Caryophyllaceae and Poaceae. Acta Physiologiae Plantarum: 37: 1-13.

Koltunow A.M. 1993. Apomixis: Embryo Sacs and Embryos Formed without Meiosis or Fertilization in Ovules. Plant Cell 5: 1425-1437.

LeWIS-Smith R.I., Walton D.W.H. and DingWall P.R. 1994. Developing the Antarctic Protected Area System: Proceedings of the SCAR/IUCN Workshop on Protected Areas, Cambridge, 29 June-2 July 1992. IUCN, Gland, Switzerland and Cambridge, UK: 137.

LeVkovsky V.P., TikHMENEV E.A. and LeVkovsky E.P. 1981. Cleistogamy in Arctic grasses. Botanitcheskij Zhurnal 66: 116-120.

LONGLY B. and WATERKEYN L. 1977. Etude de la cytocinese. I Les stades callosiques de la plaque cellulaires somatique. La Cellule 72: 197-224.

MAZZUCATO A., DEN NiJs A.P.M. and FAlCINELLI M. 1996. Estimation of parthenogenesis frequency in Kentucky bluegrass with auxin-induced parthenocarpic seeds. Crop Science 36: 9-16.

Moore D.M. 1967. Chromosome numbers of Falkland Islands angiosperms. British Antarctic Survey Bulletin 14: 69-82.

Moore D.M. 1970. Studies in Colobanthus quitensis (Kunth) Bartl. and Deschampsia antarctica Desv. II. Taxonomy, distribution and relationship. British Antarctic Survey Bulletin 23: 63-80.

NiEmann J., WoJCIECHOWSKI A. and JANOWICZ J. 2012. Identification of apomixis in the Kentacky bluegrass (Poa pratensis L.) using auxin test. Acta Societatis Botanicorum Poloniae 81: 217-221.

OLECH M. 1996. Human impact on terrestrial ecosystems in west Antarctica. Proceedings of the NIPR Symposium on Polar Biology 9: 299-306.

OLECH M. and CHWEDORZEWSKA K.J. 2011. The first appearance and establishment of alien vascular plant in natural habitats on the forefield of retreating glacier in Antarctica. Antarctic Science 23: $153-154$.

PASTORCZYK M., GieŁWANOWSKA I., R.J. and LAHUTA L.B. 2014. Changes in soluble carbohydrates in polar Caryophyllaceae and Poaceae plants in response to chilling. Acta Physiologiae Plantarum 36: 1771-1780.

PeArSE A.G.E. 1985. Histochemistry, Theoretical and Applied. 3rd ed. Churchill Livingstone, Edinburgh: 1055 pp. 
PARNiKOZA I., KOZERETSKA I. and KUNAKH V. 2011. Vascular plants of the Maritime Antarctic: origin and adaptation. American Journal of Plant Sciences 2: 382-395.

PŁachno B.J., ŚWIĄTeK P., KozIERADZKa-KisZKuRno M., MAJeskÝ L'., MARCiniUK J. and StoLARCZYK P. 2015. Are obligatory apomicts invested in the pollen tube transmitting tissue? Comparison of the micropyle ultrastructure between sexual and apomictic dandelions (Asteraceae, Lactuceae). Protoplasma 252: 1325-1333.

RoDKIEWICZ B. 1970. Callose in the cell wall during megasporogenesis in Angiosperms. Planta 93: 39-47.

RODKIEWICZ B. and BEDNARA J. 1976. Cell wall ingrowth and callose distribution in megasporogenesis in some Orchidaceae. Phytomorphology 26: 2276-2281.

RODKIEWICZ B. and GóRSKA-BRYLASS A. 1968. Callose in the walls of the developing megasporocyte and megaspores in the orchid ovule. Acta Societatis Botanicorum Poloniae 37: 19-28.

SHIMOURA T. and DIJKSTRA J. 1975. The occurrence of callose during the process of local lesion formation. Netherlands Journal of Plant Pathology 81: 107-121.

SKOTTSBeRg C. 1954. Antarctic vascular plants. Botanisk Tidsskrift 51: 330-338.

ÜNAl M., VARDAR F. and ÖZleM A. 2013. Callose in plant sexual reproduction. In: M.S.D. Kormann (ed.) Modern Tools for Genetic Engineering. InTech, Rijeka: 227 pp.

WATERKEYN L. 1971. Sur l'existance d'un "stade callosique" presente per le paroi cellulaire, au cours de la cytocinese. Comptes Rendus de l'Académie des Sciences 256: 1792-1794.

WILLEMSE M.T.M. and VAN WENT J.L. 1984. The female gametophyte. In: B.M. Johri (ed.) Embryology of angiosperms. Springer-Verlag, Berlin, Germany: 159-196.

WódKiewicz M., Galera H., GieŁwanowska I., ChwedorzewsKa K.J. and Olech M. 2013. Diaspores of the introduced species Poа аппиа L. in soil samples from King George Island (South Shetlands, Antarctic). Arctic, Antarctic and Alpine Research 45: 415-419.

Received 13 March 2016

Accepted 11 April 2016 